\title{
Pengaruh Pengetahuan Pajak Dan Kualitas Pelayanan Pajak Terhadap Kesadaran Wajib Pajak Dalam Membayar Pajak Kendaraan Bermotor Dan Dampaknya Terhadap Persepsi Atas Penerimaan Pajak
}

Muhammad Ridho Hendriyadi ${ }^{1}$

ridho.mr26@gmail.com

Linda Y. Hutadjulu ${ }^{1}$

Novalia H. Bleskadit ${ }^{1}$

Jurusan Akuntansi, Fakultas Ekonomi dan Bisnis Universitas Cenderawasih

\begin{abstract}
This study aims to determine whether there is a relationship between tax knowledge and tax service quality on taxpayer awareness in paying motorized vehicle taxes and its impact on perceptions of tax revenue. The research method used is the Path Analysis method and Sobel Test. The population of this study is the owner of motor vehicles in the Jayapura area. The research sample was 94 motorized vehicle owners who were selected by the snowball sampling technique. The type of data used is primary data. The results showed that tax knowledge and tax service quality had an effect on taxpayer awareness. However, knowledge of taxes, quality of tax services and awareness of taxpayers have no effect on perceptions of tax revenue. In addition, knowledge of taxes and the quality of tax services also have an indirect effect on the perception of tax revenue through taxpayer awareness.
\end{abstract}

Keywords: Tax Knowledge; Tax Service Quality; Taxpayer Awareness; Perception of Tax Revenues; Motor Vehicle Taxes.

\begin{abstract}
Abstrak
Tujuan dari penelitian ini adalah untuk mengetahui ada tidaknya hubungan antara pengetahuan pajak dan kualitas pelayanan pajak terhadap kesadaran wajib pajak dalam membayar pajak kendaraan bermotor dan dampaknya terhadap persepsi atas penerimaan pajak.

Adapun metode penelitian yang digunakan yaitu metode Path Analysis dan Uji Sobel. Populasi penelitian ini adalah Pemilik Kendaraan Bermotor di daerah Jayapura. Sampel penelitian sebanyak 94 orang pemilik kendaraan bermotor yang dipilih dengan teknik snowball sampling. Jenis data yang digunakan adalah data Primer.

Hasil penelitian menunjukkan bahwa pengetahuan pajak dan kualitas pelayanan pajak berpengaruh terhadap kesadaran wajib pajak. Namun pengetahuan pajak, kualitas pelayanan pajak dan kesadaran wajib pajak tidak memiliki pengaruh terhadap persepsi atas penerimaan pajak. Selain itu, pengetahuan pajak dan kualitas pelayanan pajak juga memiliki pengaruh tidak langsung terhadap persepsi atas penerimaan pajak melalui kesadaran wajib pajak.
\end{abstract}

Kata Kunci: Pengetahuan Pajak; Kualitas Pelayanan Pajak; Kesadaran Wajib Pajak; Persepsi Atas Penerimaan Pajak; Pajak Kendaraan Bermotor.

\section{Pendahuluan}

Indonesia adalah sebuah negara berkembang yang merancang pembangunan nasional untuk mewujudkan cita-cita, yaitu mewujudkan masyarakat yang adil, makmur dan sejahtera. Untuk mencapai tujuan ini, pemerintah harus memperhatikan dana atau anggaran sehingga proses pengembangan bisa berjalan dengan baik. Untuk melakukan pembangunan nasional, pemerintah membutuhkan banyak biaya. Biaya adalah dikeluarkan oleh pemerintah untuk melaksanakan pembangunan nasional ini berasal dari pendapat yang diperoleh dari hasil pemanfaatan kekayaan alam dan kontribusi dari masyarakat dalam bentuk pajak (Famiyah, 2018).

Terdapat dua sumber pendapatan di Indonesia ini, yaitu PNBP (Pendapatan Negara Bukan Pajak) dan selanjutnya yaitu pajak. Pajak dapat dibedakan antara lain pajak pusat dan pajak daerah, pajak ialah sumber dana pemerintah untuk pembangunannya (Akbar, 2019).

Menurut UU No. 28 Tahun 2009, pajak daerah diartikan sebagai iuran wajib kepada daerah yang merupakan hak perseorangan atau badan yang bersifat memaksa berdasarkan undang-undang, tanpa 
mendapat kompensasi langsung dan digunakan untuk kebutuhan 2 daerah untuk sebesar-besar kemakmuran rakyat. Pajak daerah di Indonesia dapat diklasifikasikan berdasarkan tingkatan pemerintahan daerah, yaitu pajak daerah di tingkat provinsi dan pajak daerah di tingkat kabupaten / kota. Klasifikasi pajak di atas diatur dalam UU No. 18/1997 sebagaimana telah diubah dengan UU No. 34/2000. Pemberian kekuasaan pengenaan pajak dan retribusi daerah ini diharapkan dapat semakin membuat pemerintah daerah agar selalu mengoptimalkan pendapatan asli daerah (PAD), khususnya Pajak Kendaraan Bermotor (PKB) dan Transfer Bea Masuk Kendaraan Bermotor (PBBNKB) yang salah satu pajak daerah yang memiliki potensi yang cukup besar untuk membiayai pembangunan daerah (Akbar, 2019).

Kepala Badan Pengelolaan Pendapatan Daerah (Bapenda) Provinsi Papua, Gerson Jitmau mengatakan bahwa hanya 30\% dari 240 ribu kendaraan di Papua yang membayar pajak, sehingga dapat dilihat bahwa sekitar $70 \%$ pemiliki kendaraan di Papua tidak melakukan pembayaran pajak kendaraan setiap tahunnya (Liputan6.com, 2019).

Berdasarkan data yang didapatkan dari Kantor SAMSAT Jayapura, terdapat 211.439 unit kendaraan bermotor yang terdaftar sampai tahun 2019. Jumlah ini tentunya akan memberikan jumlah pemasukan yang besar terhadap pemasukan pajak daerah. Namun, hingga akhir tahun 2019 tercatat 81.245 atau hanya sebesar 38,4\% jumlah kendaraan yang aktif membayar pajak kendaraan bermotor. Ini berarti bahwa 61,6\% individu yang memiliki kendaraan pemilik di Jayapura tidak membayar pajak ditahun 2019.

Banyak masyarakat yang enggan untuk membayar pajak kendaraan bermotor karena tidak memiliki pengetahuan yang cukup mengenai perpajakan terutama masyarakat menengah ke bawah yang tidak mengerti mengenai bagaimana tata cara pembayaran pajak, tata cara pelaporan pajak, fungsi dari dana pajak, penyaluran pajak, serta sanksi pajak. Ditambah lagi dengan adanya stigma negatif yang ada di masyarakat mengenai penyelewengan penggunaan dana pajak, yang mengakibatkan semakin sedikitnya masyarakat yang membayar pajak. Salah satu upaya yang dilakukan pemerintah daerah saat ini yaitu dengan semakin gencarnya melakukan berbagai sosialisasi melalui poster ataupun dengan melakukan kerja sama dengan polisi yaitu dengan melaksanakan razia kendaraan bermotor dan menilang orang-orang yang melanggar aturan salah satunya belum membayar pajak kendaraan bermotor. Hal ini diharapkan dapat meningkatkan kesadaran masyarakat untuk membayar pajak kendaraannya. Dengan meningkatnya kesadaran masyarakat dalam membayar pajak kendaraannya maka akan memberikan dampak jangka panjang dalam penerimaan pajaknya (Ariani, 2018).

Beberapa penelitian mengenai pengaruh tingkat pengetahuan pajak orang pribadi terhadap kesadaran dalam membayar pajak telah dilakukan untuk mengetahui sejauh mana pengaruh tingkat pengetahuan pajak terhadap kesadaran membayar pajak. Selain alasan kurangnya pengetahuan mengenai perpajakan, faktor lain yang mempengaruhi rendahnya kesadaran masyarakat dalam membayar pajak adalah fasilitas sarana dan prasarana yang diberikan oleh instansi yang dulu dianggap kurang memadai.

Pemerintah saat ini sudah mengupayakan segala hal demi meningkatkan kualitas dan kemudahan proses perpajakan bagi masyarakat, serta pelayanan pajak kendaraan bermotor. Hal tersebut dilakukan pemerintah dengan harapan dapat meningkatkan kesadaran masyarakat dalam membayar pajak kendaraan. Bentuk upaya yang dilakukan pemerintah adalah dengan menambah ruang pelayanan pajak kendaraan bermotor, seperti penempatan Samsat Corner di Mal Jayapura, mobile Samsat dan layanan Samsat box / Drive Thru. Dengan penambahan jumlah loket dan peningkatan kualitas pelayanan pajak kendaraan bermotor diharapkan masyarakat akan lebih sadar serta patuh dalam membayar pajak kendaraannya. Tentunya hal ini juga mempnegauhi pada penerimaan pajak yang akan meningkat sejalan dengan peningkatan pembayaran pajak.

Perumusan yang dibahas dalam penelitian ini adalah : (1) Apakah Pengetahuan Pajak berpengaruh terhadap Kesadaran Wajib Pajak? (2) Apakah Kualitas Pelayanan Pajak berpengaruh terhadap Kesadaran Wajib Pajak? (3) Apakah Pengetahuan Pajak dan Kualitas Pelayanan Pajak secara simultan berpengaruh terhadap Kesadaran Wajib Pajak? (4) Apakah Pengetahuan Pajak berpengaruh terhadap Persepsi Atas Penerimaan Pajak? (5) Apakah Kualitas Pelayanan Pajak berpengaruh terhadap Persepsi Atas Penerimaan Pajak? (6) Apakah Kesadaran Wajib Pajak berpengaruh terhadap Persepsi Atas Penerimaan Pajak? (7) Apakah Pengetahuan Pajak, Kualitas Pelayanan Pajak dan Kesadaran 
Wajib Pajak secara simultan berpengaruh terhadap Persepsi Atas Penerimaan Pajak? (8) Apakah terdapat pengaruh tidak langsung antara Pengetahuan Pajak terhadap Persepsi Atas Penerimaan Pajak melalui Kesadaran Wajib Pajak? (9) Apakah terdapat pengaruh tidak langsung antara Kualitas Pelayanan Pajak terhadap Persepsi Atas Penerimaan Pajak melalui Kesadaran Wajib Pajak?

Berdasarkan perumusan masalah diatas, maka tujuan penelitian adalah : (1) Menganalisis pengaruh tingkat pengetahuan pajak terhadap kesadaran wajib pajak dalam membayar pajak kendaraan bermotor. (2) Menganalisis pengaruh kualitas pelayanan pajak terhadap kesadaran wajib pajak dalam membayar pajak kendaraan bermotor. (3) Menganalisis pengaruh pengetahuan pajak dan kualitas pelayanan pajak terhadap kesadaran wajib pajak dalam membayar pajak kendaraan bermotor secara simultan. (4) Menganalisis pengaruh pengetahuan pajak terhadap persepsi atas penerimaan pajak. (5) Menganalisis pengaruh kualitas pelayanan pajak terhadap persepsi atas penerimaan pajak. (6) Menganalisis pengaruh kesadaran wajib pajak terhadap persepsi atas penerimaan pajak. (7) Menganalisis pengaruh pengetahuan pajak, kualitas pelayanan pajak dan kesadaran wajib pajak terhadap persepsi atas penerimaan pajak secara simultan. (8) Menganalisis pengaruh tidak langsung antara pengetahuan pajak terhadap persepsi atas penerimaan pajak melalui kesadaran wajib pajak. (9) Menganalisis pengaruh tidak langsung antara kualitas pelayanan pajak terhadap persepsi atas penerimaan pajak melalui kesadaran wajib pajak.

\section{Kerangka Teoritis Dan Pengembangan Hipotesis \\ 2.1 Pengertian Pajak}

Dalam hal jumlah penerimaan pajak yang diterima oleh negara, penerimaan pajak adalah pendapatan dominan dari semua penerimaan negara. Pengertian pajak berdasarkan Pasal 1 angka 1 Undang-Undang No. 28 Tahun 2007 tentang ketentuan umum dan tata cara perpajakan adalah sebagai berikut: "Pajak adalah sumbangan wajib kepada negara yang menjadi hak pribadi orang atau badan yang bersifat memaksa berdasarkan undang-undang, tanpa menerima kompensasi langsung dan digunakan untuk kepentingan negara dan sebesar-besarnya kemakmuran rakyat”.

\subsection{Pengertian Pajak Kendaraan Bermotor}

Menurut Perda no 2 thn 2015 tentang Pajak Kendaraan Bermotor, Pajak Kendaraan Bermotor adalah pajak yang dipungut atas kepemilikan dan/atau penguasaan kendaraan bermotor

\subsection{Pengertian Wajib Pajak}

Pengertian wajib pajak menurut Undang-undang KUP Nomor 28 Tahun 2007 yaitu: Wajib pajak adalah orang pribadi atau badan, termasuk pembayar pajak, pemotong pajak, dan pemungut pajak, yang memiliki hak dan kewajiban perpajakan sesuai dengan ketentuan peraturan perundang-undangan perpajakan.

\subsection{Pengertian Pengetahuan}

Definisi pengetahuan menurut KBBI adalah segala sesuatu yang diketahui, atau segala sesuatu yang diketahui berkenaan dengan hal (mata pelajaran) (Departemen Pendidikan Nasional, 2008). Dalam kaitanya dengan penelitian ini, pengetahuan wajib pajak tentang perpajakan adalah segala sesuatu yang diketahui oleh wajib pajak mengenai perpajakan, baik dalam segi sistem perpajakan, tata cara pembayaran pajak, pelaporan pajak, maupun sanksi perpajakan.

\subsection{Pengertian Kualitas Pelayanan}

Menurut Moenir (2005:47) pelayanan adalah proses pemenuhan kebutuhan melalui aktivitas orang lain secara langsung. Sedangkan menurut Kotler (2003:464) bahwa pelayanan adalah semua tindakan atau kinerja yang dapat ditawarkan satu pihak kepada pihak lain suatu tindakan atau kinerja yang diberikan oleh seseorang kepada orang lain.

\subsection{Pengertian Kesadaran Wajib Pajak}

Menurut Nasution (2003:62) dalam Ilhamsyah (2016), kesadaran wajib pajak merupakan sikap yang memahami dan bersedia menjalankan kewajibannya membayar pajak serta telah melaporkan seluruh penghasilannya tanpa disembunyikan sesuai dengan ketentuan yang berlaku. Kesadaran wajib 
pajak merupakan suatu kondisi dimana wajib pajak memahami ketentuan perpajakan dan melaksanakannya dengan baik (Pratiwi 2014:228).

\subsection{Penelitian Terdahulu dan Pengembangan Hipotesis Pengetahuan Pajak dan Kesadaran Wajib Pajak}

Berdasarkan penelitian yang dilakukan oleh Kurniati, dkk (2016) terdapat hubungan yang positif antara pengetahuan pajak terhadap kesadaran wajib pajak. Berdasarkan pernyataan di atas maka peneliti mengajukan hipotesis sebagai berikut:

H1 : Kualitas pelayanan pajak berpengaruh terhadap kesadaran wajib pajak

\section{Kualitas Pelayanan Pajak dan Kesadaran Wajib Pajak}

Berdasarkan penelitian yang dilakukan Kurniati, dkk (2016) Kualitas pelayanan pajak berpengaruh positif terhadap kesadaran wajib pajak. Berdasarkan pernyataan di atas maka peneliti mengajukan hipotesis sebagai berikut:

H2 : Kualitas pelayanan pajak berpengaruh terhadap kesadaran wajib pajak

\section{Pengetahuan Pajak, Kualitas Pelayanan Pajak dan Kesadaran Wajib Pajak}

Berdasaran penelitian Kurniati, dkk (2016) pengetahuan pajak dan kualitas pelayanan pajak berpengaruh positif terhadap kesadaran wajib pajak. Berdasarkan pernyataan di atas maka peneliti mengajukan hipotesis sebagai berikut:

H3 : Pengetahuan pajak dan kualitas pelayanan pajak secara simultan berpengaruh terhadap

kesadaran wajib pajak

\section{Pengetahuan Pajak dan Persepsi Atas Penerimaan Pajak}

Berdasarkan penelitian yang dilakukan oleh Hartinah dalam Dewi dan Retnaningtyas (2013) pengetahuan pajak berpengaruh positif terhadap penerimaan pajak. Berdasarkan pernyataan di atas maka peneliti mengajukan hipotesis sebagai berikut:

H4 : Pengetahuan pajak berpengaruh terhadap persepsi atas penerimaan pajak

\section{Kualitas Pelayanan Pajak dan Persepsi Atas Penerimaan Pajak}

Berdasarkan penelitian yang dilakukan oleh Fernado, dkk (2013) kualitas pelayanan pajak berpengaruh positif terhadap penerimaan pajak. Sedangkan menurut Oktaviani, dkk (2017) Pelayanan yang dilakukan fiskus tidak berpengaruh signifikan terhadap Penerimaan Pajak. Berdasarkan pernyataan di atas maka peneliti mengajukan hipotesis sebagai berikut:

H5 : Kualitas pelayanan pajak berpengaruh terhadap persepsi atas penerimaan pajak

\section{Kesadaran Wajib Pajak dan Persepsi Atas Penerimaan Pajak}

Berdasarkan penelitan yang dilakukan oleh Fauziyah dalam Dewi dan Retnaningtyas (2013) dan penelitian yang dilakukan oleh Aditya (2013) kesadaran wajib pajak berpengaruh positif terhadap penerimaan pajak. Berdasarkan pernyataan di atas maka peneliti mengajukan hipotesis sebagai berikut:

H6 : Kesadaran wajib pajak berpengaruh terhadap persepsi atas penerimaan pajak

\section{Pengetahuan Pajak, Kualitas Pajak, dan Kesadaran Wajib Pajak}

Berdasarkan penelitian yang dilakukan oleh Fraternesi, Fauziyah, dan Hartinah dalam Dewi dan Retnaningtyas (2013) pengetahuan pajak, kualitas pelayanan pajak dan kesadaran wajib pajak berpengaruh positif terhadap penerimaan pajak. Berdasarkan pernyataan di atas maka peneliti mengajukan hipotesis sebagai berikut:

H7: Pengetahuan pajak, kualitas pelayanan pajak dan kesadaran wajib pajak secara simultan berpengaruh terhadap persepsi atas penerimaan pajak

\section{Pengetahuan Pajak, Persepsi Atas Penerimaan Pajak dan Kesadaran Wajib Pajak}

Berdasarkan penelitian yang dilakukan oleh Kurniati, dkk (2016) terdapat hubungan yang positif antara pengetahuan pajak terhadap kesadaran wajib pajak sedangkan menurut penelitian yang 
dilakukan oleh Fauziyah dalam Dewi dan Retnaningtyas Widuri (2013) kesadaran wajib pajak berpengaruh positif terhadap penerimaan pajak. Sedangkan menurut penlitian yang dilakukan oleh Herryanto dan Agus (2013) Kesadaran Wajib Pajak berpengaruh negatif terhadap penerimaan pajak. Berdasarkan pernyataan di atas maka peneliti mengajukan hipotesis sebagai berikut:

H8: Terdapat pengaruh tidak langsung antara pengetahuan pajak terhadap persepsi atas penerimaan pajak melalui kesadaran wajib pajak

\section{Kualitas Pelayanan Pajak, Persepsi Atas Penerimaan Pajak dan Kesadaran Wajib Pajak}

Berdasarkan penelitian yang dilakukan oleh Kurniati, dkk (2016) Kualitas pelayanan pajak berpengaruh positif terhadap kesadaran wajib pajak sedangkan menurut penelitian yang dilakukan oleh Fauziyah dalam Dewi dan Retnaningtyas (2013) kesadaran wajib pajak berpengaruh positif terhadap penerimaan pajak. Berdasarkan pernyataan di atas maka peneliti mengajukan hipotesis sebagai berikut:

H9: Terdapat pengaruh tidak langsung antara kualitas pelayanan pajak terhadap persepsi atas penerimaan pajak melalui kesadaran wajib pajak

\section{Metode Penelitian}

Penelitian ini mengunakan metode penelitian kuantitatif. Populasi dalam penelitian ini adalah wajib pajak yang memiliki kendaraan bermotor di daerah Jayapura. Sampel dalam penelitian ini akan diambil 100 orang sebagai sampel penelitian dengan menggunakan teknik snowball sampling. Penelitian ini mengunakan data primer dengan teknik pengumpulan data dengan cara menyebarkan kuisioner online.

\section{Hasil Dan Pembahasan \\ Pengaruh Pengetahuan Pajak terhadap Kesadaran Wajib Pajak}

Hasil pengujian hipotesis yang dilakukan dengan metode analisis jalur menunjukkan bahwa Pengetahuan Pajak terhadap Kesadaran Wajib Pajak menunjukkan nilai koefisien jalur sebesar 0,493 dengan nilai t-statistic sebesar 6,719 nilai tersebut lebih besar dari nilai t tabel 1,98. Hal ini berarti Pengetahuan Pajak memiliki pengaruh dan signifikan pada 0,000 terhadap Kesadaran Wajib Pajak yang berarti sesuai dengan hipotesis pertama ( $\left.\mathrm{Ha}_{1}\right)$ diterima.

Hasil penelitian ini sejalan dengan penelitian yang dilakukan oleh Dwi Ariani (2018) yang menunjukkan bahwa Pengetahuan Pajak berpengaruh terhadap Kesadaran Wajib Pajak.

\section{Pengaruh Kualitas Pelayanan Pajak terhadap Kesadaran Wajib Pajak}

Hasil pengujian hipotesis yang dilakukan dengan metode analisis jalur menunjukkan bahwa Kualitas Pelayanan Pajak terhadap Kesadaran Wajib Pajak menunjukkan nilai koefisien jalur sebesar 0,422 dengan nilai t-statistic sebesar 5,752 nilai tersebut lebih besar dari nilai t tabel 1,98. Hal ini berarti Kualitas Pelayanan Pajak memiliki pengaruh dan signifikan pada 0,000 terhadap Kesadaran Wajib Pajak yang berarti sesuai dengan hipotesis pertama. Hal ini berarti Hipotesis Pertama $\left(\mathrm{Ha}_{2}\right)$ diterima.

Hasil penelitian ini sejalan dengan penelitian yang dilakukan oleh Dwi Ariani (2018) yang menunjukkan bahwa Kualitas Pelayanan Pajak berpengaruh terhadap Kesadaran Wajib Pajak.

\section{Pengetahuan Pajak dan Kualitas Pelayanan Pajak terhadap Kesadaran Wajib Pajak}

Hasil pengujian hipotesis yang dilakukan dengan metode analisis jalur menunjukkan bahwa Pengetahuan Pajak dan Kualitas Pelayanan Pajak terhadap Kesadaran Wajib Pajak menunjukkan nilai koefisien jalur sebesar 0,493 dan 0,422 dengan nilai t-statistic sebesar 6,719 dan 5,752 nilai tersebut lebih besar dari nilai t tabel 1,98. Hal ini berarti Pengetahuan Pajak dan Kualitas Pelayanan Pajak memiliki pengaruh dan signifikan pada 0,000 dan 0,000 terhadap Kesadaran Wajib Pajak yang berarti sesuai dengan hipotesis pertama. Ha ini berarti Hipotesis Pertama ( $\left.\mathrm{Ha}_{3}\right)$ diterima.

Hasil penelitian ini sejalan dengan penelitian yang dilakukan oleh Dwi Ariani (2018) yang menunjukkan bahwa Pengetahuan Pajak dan Kualitas Pelayanan Pajak berpengaruh terhadap Kesadaran Wajib Pajak. 


\section{Pengaruh Pengetahuan Pajak terhadap Persepsi atas Penerimaan Pajak}

Hasil pengujian hipotesis yang dilakukan dengan metode analisis jalur menunjukkan bahwa Pengetahuan Pajak terhadap Persepsi atas Penerimaan Pajak menunjukkan nilai koefisien jalur sebesar 0,125 dengan nilai t-statistic sebesar 1,197 nilai tersebut lebih kecil dari nilai t tabel 1,98 . Hal ini berarti Pengetahuan Pajak tidak memiliki pengaruh dan signifikan pada 0,235 terhadap Persepsi atas Penerimaan Pajak yang berarti tidak sesuai dengan hipotesis pertama. Hal ini berarti Hipotesis Pertama ( $\left.\mathrm{Ha}_{4}\right)$ ditolak.

Hasil penelitian ini bertentangan dengan penelitian yang dilakukan oleh Dwi Ariani (2018) yaitu bahwa terdapat pengaruh langsung yang signifikan antara Pengetahuan Pajak terhadap Persepsi atas Penerimaan Pajak.

\section{Pengaruh Kualitas Pelayanan Pajak terhadap Persepsi atas Penerimaan Pajak}

Hasil pengujian hipotesis yang dilakukan dengan metode analisis jalur menunjukkan bahwa Kualitas Pelayanan Pajak terhadap Persepsi atas Penerimaan Pajak menunjukkan nilai koefisien jalur sebesar -0,100 dengan nilai t-statistic sebesar -1,006 nilai tersebut lebih kecil dari nilai t tabel 1,98. Hal ini berarti Kualitas Pelayanan Pajak tidak memiliki pengaruh dan signifikan pada 0,317 terhadap Persepsi atas Penerimaan Pajak yang berarti tidak sesuai dengan hipotesis pertama. Hal ini berarti Hipotesis Pertama (Ha5) ditolak.

Hasil penelitian ini sejalan dengan penelitian yang dilakukan oleh Oktaviani, dkk (2017) yang menunjukkan bahwa Pelayanan Fiskus tidak berpengaruh signifikan terhadap Penerimaan Pajak. Namun, hal ini bertentangan dengan penelitian yang dilakukan oleh Dwi Ariani (2018) dimana Kualitas Pelayanan Pajak berpengaruh signifikan terhadap Penerimaan Pajak.

\section{Pengaruh Kesadaran Wajib Pajak terhadap Persepsi atas Penerimaan Pajak}

Hasil pengujian hipotesis yang dilakukan dengan metode analisis jalur menunjukkan bahwa Kesadaran Wajib Pajak terhadap Persepsi atas Penerimaan Pajak menunjukkan nilai koefisien jalur sebesar 0,667 dengan nilai t-statistic sebesar 5,472 nilai tersebut lebih besar dari nilai t tabel 1,98. Hal ini berarti Kesadaran Wajib Pajak memiliki pengaruh dan signifikan pada 0,000 terhadap Persepsi atas Penerimaan Pajak yang berarti sesuai dengan hipotesis pertama. Hal ini berarti Hipotesis Pertama (Ha6) diterima.

Hasil penelitian ini sejalan dengan penelitian yang dilakukan oleh Dwi Ariani (2018) yang menunjukkan bahwa Kesadaran Wajib Pajak berpengaruh terhadap Persepsi atas Penerimaan Pajak.

\section{Pengaruh Pengetahuan Pajak, Kualitas Pelayanan Pajak dan Kesadaran Wajib Pajak terhadap Persepsi atas Penerimaan Pajak}

Hasil pengujian hipotesis yang dilakukan dengan metode analisis jalur menunjukkan bahwa Pengetahuan Pajak, Kualitas Pelayanan Pajak dan Kesadaran Wajib Pajak terhadap Persepsi atas Penerimaan Pajak menunjukkan nilai koefisien jalur sebesar 0,125, -0,100 dan 0,667 dengan nilai tstatistic sebesar 1,197, -1,006 dan 5,472. Hal ini menunjukan terdapat dua variabel yang memiliki nilai lebih kecil dari nilai $t$ tabel dan satu variabel yang memiliki nilai lebih besar dari nilai tabel sebesar 1,98. Hal ini berarti Pengetahuan Pajak, Kualitas Pelayanan Pajak dan Kesadaran Wajib Pajak tidak memiliki pengaruh dan signifikan pada 0,235, 0,317 dan 0,000 terhadap Persepsi atas Penerimaan Pajak yang berarti tidak sesuai dengan hipotesis pertama. Hal ini berarti Hipotesis Pertama (Ha7) ditolak.

\section{Pengaruh tidak langsung Pengetahuan Pajak terhadap Persepsi atas Penerimaan Pajak melalui Kesadaran Wajib Pajak}

Hasil pengujian hipotesis yang dilakukan dengan metode uji sobel menunjukkan bahwa pengaruh tidak langsung Pengetahuan Pajak terhadap Persepsi atas Penerimaan Pajak melalui Kesadaran Wajib Pajak menunjukkan nilai t-hitung sebesar 4,39 nilai tersebut lebih besar dari nilai $\mathrm{t}$ 
tabel 1,98. Hal ini berarti Pengetahuan Pajak memiliki pengaruh tidak langsung terhadap Persepsi atas Penerimaan Pajak melalui Kesadaran Wajib Pajak yang berarti sesuai dengan hipotesis pertama. Hal ini berarti Hipotesis Pertama (Ha8) diterima.

Hasil penelitian ini sejalan dengan penelitian yang dilakukan oleh Dwi Ariani (2018) yang mengatakan terdapat pengaruh tidak langsung yang signifikan antara Pengetahuan Pajak terhadap Penerimaan Pajak melalui Kesadaran Wajib Pajak.

\section{Pengaruh tidak langsung Kualitas Pelayanan Pajak terhadap Persepsi atas Penerimaan Pajak melalui Kesadaran Wajib Pajak}

Hasil pengujian hipotesis yang dilakukan dengan metode uji sobel menunjukkan bahwa pengaruh tidak langsung Kualitas Pelayanan Pajak terhadap Persepsi atas Penerimaan Pajak melalui Kesadaran Wajib Pajak menunjukkan nilai t-hitung sebesar 5,98 nilai tersebut lebih besar dari nilai $\mathrm{t}$ tabel 1,98. Hal ini berarti Kualitas Pelayanan Pajak memiliki pengaruh tidak langsung terhadap Persepsi atas Penerimaan Pajak melalui Kesadaran Wajib Pajak yang berarti sesuai dengan hipotesis pertama. Hal ini berarti Hipotesis Pertama (Ha9) diterima.

Hasil penelitian ini sesuai dengan penelitian yang dilakukan oleh Dwi Ariani (2018) yang mengatakan terdapat pengaruh tidak langsung yang signifikan antara Kualitas Pelayanan Pajak terhadap Penerimaan Pajak melalui Kesadaran Wajib Pajak.

\section{Penutup}

\subsection{Kesimpulan}

Berdasarkan hasil yang diperoleh dari pengolahan data dapat diambil kesimpulan (1) pengetahuan pajak berpengaruh langsung terhadap kesadaran wajib pajak, (2) kualitas pelayanan pajak berpengaruh langsung terhadap kesadaran wajib pajak, (3) pengetahuan pajak dan kualitas pelayanan pajak berpengaruh terhadap kesadaran wajib pajak, (4) pengetahuan pajak tidak berpengaruh terhadap persepsi atas penerimaan pajak, (5) kualitas pelayanan pajak tidak berpengaruh terhadap persepsi atas penerimaan pajak, (6) kesadaran wajib pajak berpengaruh langsung terhadap persepsi atas penerimaan pajak, (7) pengetahuan pajak, kualitas pelayanan pajak dan kesadaran pajak tidak berpengaruh terhadap persepsi atas penerimaan pajak, (8) pengetahuan pajak berpengaruh tidak langsung terhadap perepsi atas penerimaan pajak melalui kesadaran wajib pajak, dan (9) kualitas pelayanan pajak berpengaruh tidak langsung terhadap persepsi atas penerimaan pajak melalui kesadaran wajib pajak.

\section{Daftar Pustaka}

Akbar, O. C. (2019). Pengaruh Sosialisasi Pajak, Pegetahuan Pajak, Kualitas Pelayanan Sanksi Pajak dan Kesadaran Pajak Terhadap Kepatuhan Kendaraan Bermotor. Retrieved from https://dspace.uii.ac.id/bitstream/handle/123456789/14013/SKRIPSI

OKKY.pdf? sequence $=1 \&$ is Allowed $=\mathrm{y}$

Ariani, D. W. I. (2018). pengaruh pengetahuan pajak dan kualitas pelayanan pajak terhadap kesadaran wajib pajak dalam membayar pajak kendaraan bermotor dan dampaknya terhadap penerimaan pajak. Retrieved from http://repository.uinjkt.ac.id/dspace/bitstream/123456789/40416/1/DWI ARIANI-FEB.pdf

BPRD. (2017). Pajak Kendaraan Bermotor (PKB). Retrieved March 20, 2020, from bprd.jakarta.go.id website: https://bprd.jakarta.go.id/pajak-kendaraan-bermotor/

Cahyono, Y. T. (2017). analisis faktor-faktor yang mempengaruhi penerimaan pajak (Studi Empirik di Kantor Pelayanan Pajak Pratama Surakarta). Riset Akuntansi Dan Keuangan Indonesia, 2(2), 163-175. https://doi.org/10.23917/reaksi.v2i2.4923

Ciputrauceo.com. (2016). Kualitas Pelayanan: Dimensi dan Cara Mengukurnya. Retrieved March 29, 2020, from http://ciputrauceo.net/blog/2016/2/18/kualitas-pelayanan-dimensi-dan-caramengukurnya

Departemen Pendidikan Nasional. (2008). Kamus Besar Bahasa Indonesia. Balai Pustaka.

Famiyah, T. (2018). Analisis faktor internal dan eksternal yang mempengaruhi kepatuhan wajib pajak orang pribadi. Retrieved from http://eprints.perbanas.ac.id/3811/6/artikel ilmiah.pdf 
Febriyanti, I. (2013). Pengaruh Kewajiban Kepemilikan NPWP, Pemeriksaan Pajak Dan Penagihan Pajak Terhadap Penerimaan Pajak (Pada Kantor Pelayanan Pajak Pratama di Wilayah Jakarta Selatan). Ekonomi Akuntansi Pajak. Retrieved from http://repository.uinjkt.ac.id/dspace/bitstream/123456789/24018/1/Skripsi Irna Febriyanti.pdf

Liputan6.com. (2019). Pemilik Kendaraan di Papua Malas Bayar Pajak. Retrieved March 27, 2020, from https://www.liputan6.com/regional/read/4028831/pemilik-kendaraan-di-papua-malas-bayarpajak

Nurmantu, P. D. S., \& Mas Rasmini, S. M. S. (2011). Dasar-Dasar Perpajakan. Modul 1, 1-46. https://doi.org/KDT

Oktaviani, R. M., Hardiningsih, P., \& Srimindari, C. (2017). Kepatuhan Wajib Pajak Memediasi Determinan Penerimaan Pajak Penghasilan. Jurnal Akuntansi, 21(2), 318. https://doi.org/10.24912/ja.v21i2.201

Parasuraman, A. V. A. Z. dan L. L. B. (n.d.). SERVQUAL: A Multiple-Item Scale for Measuring Consumer Perceptions of Service Quality. Retrieved March 28, 2020, from 2002 website: https://books.google.co.id/books?hl=id\&lr=\&id=Rt96wAigg2oC\&oi=fnd\&pg=PA140\&dq=SER VQUAL:+A+Multiple-

Item+Scale+for+Measuring+Consumer+Perceptions+of+Service+Quality\&ots=pSx2aDwIDM\&s ig=IFfvF7ucIDF8fzx6d_FzzvcrY_4\&redir_esc=y\#v=onepage\&q=SERVQUAL\%3A A Multip

Sari, F. (2017). Pengaruh Kesadaran Membayar Pajak, Pengetahuan dan Pemahaman Peraturan Perpajakan, Kualitas Layanan dan Kondisi Keuangan Terhadap Kemauan Membayar Pajak Wajib Pajak Orang Pribadi. from http://repository.umy.ac.id/bitstream/handle/123456789/10319/BAB II.pdf? sequence $=6 \&$ isAllowed $=\mathrm{y}$

Sugiyono. (2013). Metode Penelitian Kuantitatif Kualitatif dan $R$ \& $D$. Retrieved from http://digilib.unila.ac.id/10355/16/BAB III.pdf

Undang-Undang No. 28 Tahun 2007. (n.d.). Ketentuan Umum dan Tata Cara Perpajakan. Retrieved from https://drive.google.com/file/d/0B1YgKjfTiarIOFZxRGxfM1ZDQ1k/edit

www.indonesiastudents.com. (2017). Pengertian Kesadaran. Retrieved May 15, 2020, from https://www.indonesiastudents.com/4-pengertian-kesadaran-menurut-para-ahli-dan-jenisnyalengkap/ 